\title{
LORD OF THE FLIES: POLLINATION OF DRACULA ORCHIDS
}

\author{
Lorena Endara ${ }^{1,2,5}$, David A. Grimaldi ${ }^{3} \&$ BitTy A. Roy ${ }^{4}$ \\ ${ }^{1}$ Florida Museum of Natural History, University of Florida, P.O. Box 17800. Gainesville, Florida 32611, U.S.A. \\ ${ }^{2}$ Department of Botany, University of Florida, 220 Bartram Hall, Gainesville, Florida 32611, U.S.A. \\ ${ }^{3}$ Division of Invertebrate Zoology, American Museum of Natural History, \\ Central Park West at 79th St. New York, N.Y. 1002426, U.S.A. \\ ${ }^{4}$ Center for Ecology and Evolutionary Biology, University of Oregon, Eugene, Oregon 97403 \\ ${ }^{5}$ Author for correspondence: lendara@flmnh.ufl.edu
}

\begin{abstract}
The labellum of Dracula orchids looks and smells like mushrooms, and biologists have long hypothesized mushroom mimicry in which mushroom-associated (mycophilous) flies accidentally pollinate these flowers while laying their eggs. In the cloud forest of Ecuador, we observed flower morphology, pollinators and the mechanisms of pollination in two species, Dracula lafleurii Luer \& Dalström and D. felix (Luer) Luer. The orchids are visited and pollinated by drosophilid mycophilous flies of the genus Zygothrica, which normally complete part of their life cycles on mushrooms. While these flies court and mate in the flowers, and in the process, pollinate them, they apparently do not lay their eggs in the flowers. The pollination mechanism of Dracula occurs when pollinators' thoraces are trapped by the incurved flaps of the rostellum which creates an angle between the scutellum and the abdomen for the removal and deposition of the pollinia, a novel feature previously not describe in orchids.
\end{abstract}

Resumen. La forma y el olor de los labelos de las orquídeas del género Dracula se asemejan a hongos, y por mucho tiempo se ha mantenido la hipótesis de que estas orquídeas mimetizan hongos y dípteros con ciclos de vida asociados con los hongos (micófilos) accidentalmente polinizarían estas flores mientras ovopositan. La morfología floral, los polinizadores y mecanismos de polinización fueron estudiados en Dracula lafleurii Luer \& Dalström and D. felix (Luer) Luer en un bosque nublado de Ecuador. Estas orquídeas son efectivamente visitadas en su mayoría por moscas micófilas pero son polinizadas únicamente por moscas drosofilidas del género Zygothrica cuyos ciclos de vida están estrechamente asociados con hongos. Estas moscas realizan despliegues de cortejo y apareamiento en las superficies de las flores de Dracula estudiadas y en este proceso también las polinizan, aparentemente sin ovopositar. El mecanismo de polinización de Dracula ocurre cuando los tóraxes de los polinizadores son atrapados por los márgenes incurvados del rostelo, lo cual crea un ángulo entre el escutelo y el abdomen apropiado para la remoción y deposición de los polinios, una característica que hasta ahora no había sido reportada en las orquídeas.

KEY wORDS: cloud forest, fly pollination; mycophilous; odor; pollinator behavior; Zygothrica

Introduction. Orchids in the genus Dracula have long been suspected to be mushroom mimics. They have a cupped labellum that is usually lined with parallel or radiating ridges that resembles the cap and gills of an inverted mushroom, dark-spotted sepals on a light background, long sepaline tails, and sometimes a mushroom-like odor. These characteristics suggest that Dracula flowers attract saprophagous or mycophagous insects that accidentally act as pollinators (Van der Pijl \& Dodson 1966, Vogel 1978, Endress 1996, Proctor et. al. 1996, Pridgeon et al. 2005). Moreover, Vogel
(1978) hypothesized a pollination mechanism in which the pollinia adhere to the backs of small mycophagous flies while they attempt to lay eggs on the flowers.

Dracula is a genus of unusual orchids that occurs in the moist and shady montane cloud forests of tropical America. The name means little dragon and pays homage to the 'chimaera' of Reichenbach (Luer 1993), as well as to the extravagant display of the flowers' widespread sepals with long, pendant sepaline tails that resemble flying bats (Luer 1978, Luer 1993). Comprising ca. 148 mostly epiphytic 
species, Dracula can be found mostly in pristine forests and less frequently in disturbed habitats from southern Mexico to Peru (Luer 1993). The genus Dracula belongs to the most diverse subtribe of Neotropical orchids, the Pleurothallidinae, which comprises 5 to $8 \%$ of the floristic diversity of the Neotropics (Jørgensen \& León-Yánez, 1999), and are a mostly fly-pollinated group (Van der Pijl \& Dodson 1966, Chase 1985, Dressler 1993, Duque 1993, Christensen 1994, Endress 1996, Borba \& Semir 2001, Pridgeon et al. 2001, Van der Cingel 2001, Blanco \& Barboza 2005, Pridgeon 2005, AlboresOrtiz \& Sosa, 2006, Barbosa et al. 2009).

In this paper we describe the pollination biology of these remarkable putative mushroom mimics in their native habitats, with a particular focus on the diversity and visitation rates of floral visitors to the flowers of Dracula lafleurii Luer \& Dalström with a few additional observations from $D$. felix (Luer) Luer.

\section{Material and methods}

Species and study sites.- Field studies were conducted during the rainy season (January to May) of 1999 and 2002 at Los Cedros Biological Reserve in northwestern Ecuador $\left(00^{\circ} 18.519^{\prime} \mathrm{N}, 78^{\circ} 46.760 \mathrm{~W}\right)$, in the buffer zone of the Cotacachi-Cayapas Ecological Reserve. The Los Cedros Reserve protects 6600 hectares of montane cloud forest from 1200 to 2200 m elevation. Due to the altitudinal gradient, a wide diversity of microhabitats can be found in this reserve where 14 Dracula species have been reported (Luer and Escobar 1994, www.tropicos.org). The local annual rainfall reaches $3225 \mathrm{~mm}$ with a pronounced dry period during the months of June and July (J. de Coux, pers. comm. 2002). Two Dracula species that occurred at different elevations and microhabitats within Los Cedros Biological Reserve were studied. Plants of Dracula lafleurii were abundant along the Los Cedros River, in the lower region of the reserve (from 1260 to $1300 \mathrm{~m}$ ). Dracula felix occurs at higher elevations, along the mountain ridges above the research facilities (1640$1800 \mathrm{~m})$.

Floral morphology.- The floral morphology and secretions of these flowers were examined. The flowers produced no measurable nectar, so to determine whether small amounts of sugar were nonetheless present, we rubbed Combur ${ }^{\circledR}$ test strips to 8 flowers from approximately 5 individual plants per species (it is not always possible to determine genetic individuals due to sympodial growth and close proximity) on the first day of anthesis.

Floral visitors.- All observations were performed between 0600 to $1700 \mathrm{hr}$, with $760 \mathrm{hr}$ of observations being made. Detailed observations of insect activity were registered for 5 and 47 flowers of Dracula lafleurii and D. felix, respectively. Pollinia removal or deposition was observed with a 10x-magnifying lens and complemented with photographic documentation. Notes were taken on the behavior of the visiting flies used the terminology defined by Grimaldi (1987). After observations were completed, some visitors and pollinators were captured with an aspirator or small plastic bags and then preserved in $70 \%$ ethanol for identification. Herbarium specimens of the plants $(L$. Endara 289-L. Endara 305) were deposited in the herbarium of the Pontificia Universidad Católica del Ecuador (QCA). Fly specimens were identified by D. Grimaldi and deposited in the Division of Invertebrate Zoology of the American Museum of Natural History. Identifications of drosophilids required dissection of male genitalia and examination with compound microscopy.

\section{Results}

Flower morphology.- Dracula felix and D. lafleurii have different inflorescence orientation and floral presentation (Luer 1993). Dracula felix produces erect or ascending peduncles that bear a single cupshaped flower (Fig. 1a). Unlike D. felix, but similar to the majority of the species in the genus, the flowers of Dracula lafleurii resemble an open umbrella and are borne from descending, spreading peduncles (Fig. 1b). When fully open, the flower faces downward and the sepaline tails (long tail-like extensions of the sepals, $8-9 \mathrm{~cm}$ long) expand outwards. The two species have different degrees of floral pubescence and color patterns (Fig 1a versus $1 \mathrm{~b}$ ). In both species, the petals are parallel to the column (gynoecium) and are small ( $3 \mathrm{~mm}$ long $\times 2 \mathrm{~mm}$ wide), oblong structures with the lamina containing central brown to purple spots, and a bivalvate, papillate apex, a diagnostic character of this genus (Luer 1993, see 


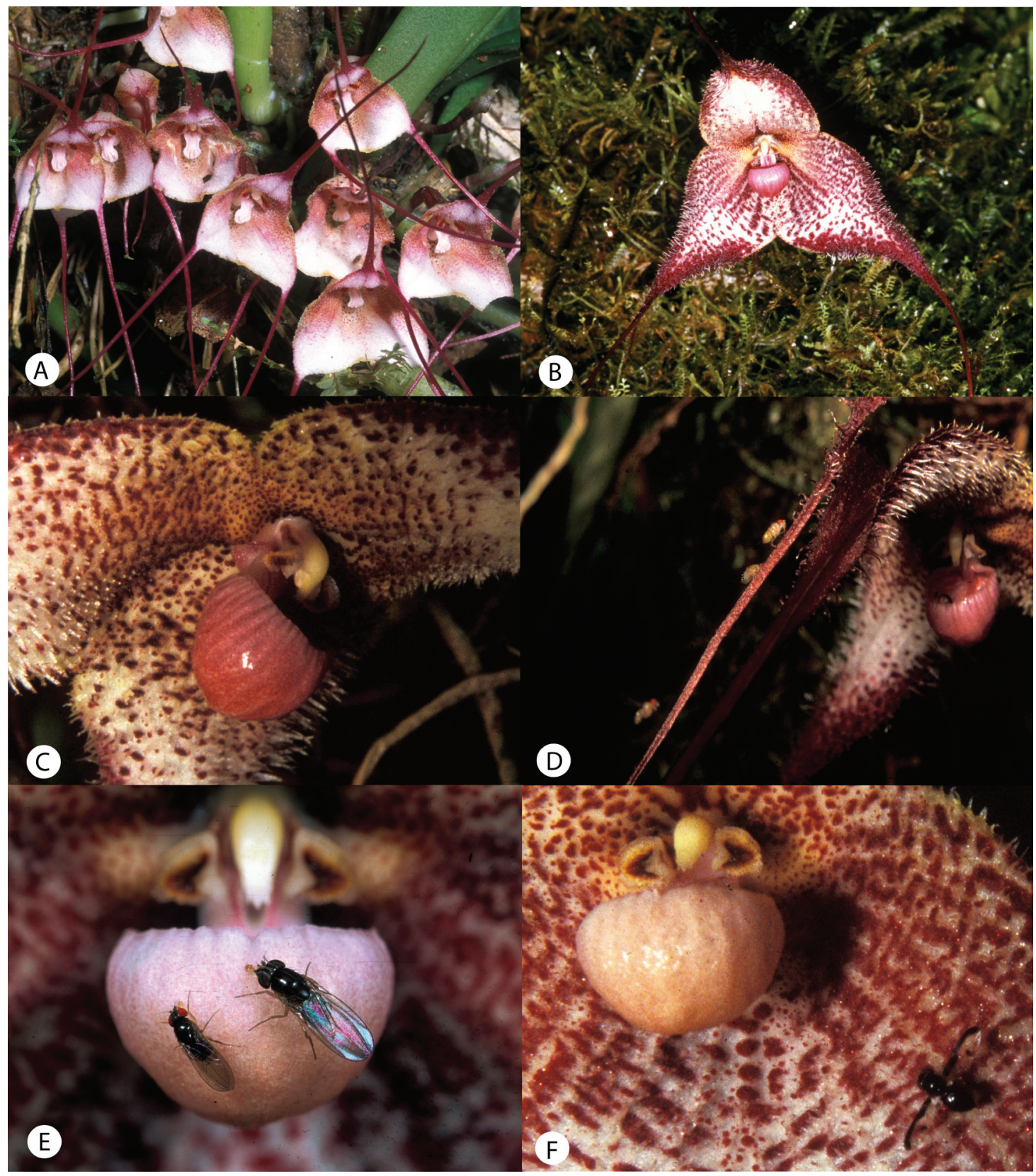

FIGURE 1. A - Dracula felix showing mass flowering and cup-shaped flowers; B — Dracula lafleurii showing successive flowering and umbrella-like flowers; C - Glossy film on labellum of D. lafleurii, which is present only on the first day the flowers are open (anthesis); D — Zygothrica flies landing on sepaline tails of D. lafleurii; E — Hirtodosophila sp. (left) and Zygothrica antedispar (right) lapping the epichile of D. laffleurii; $\mathrm{F}$ - Zygothrica paraldrichi performing the "scissoring" wing display on a flower of D. laffleurii.

Fig. 2c). The column is a rigid structure of the same size or slightly longer than the petals $(3 \mathrm{~mm}$ long x $1.5 \mathrm{~mm}$ wide excluding the column foot) and in both species it contains small raphide encrustations (intracellular crystals; Fig. 2a). The apex of the column is irregularly dentate and contains the anther 

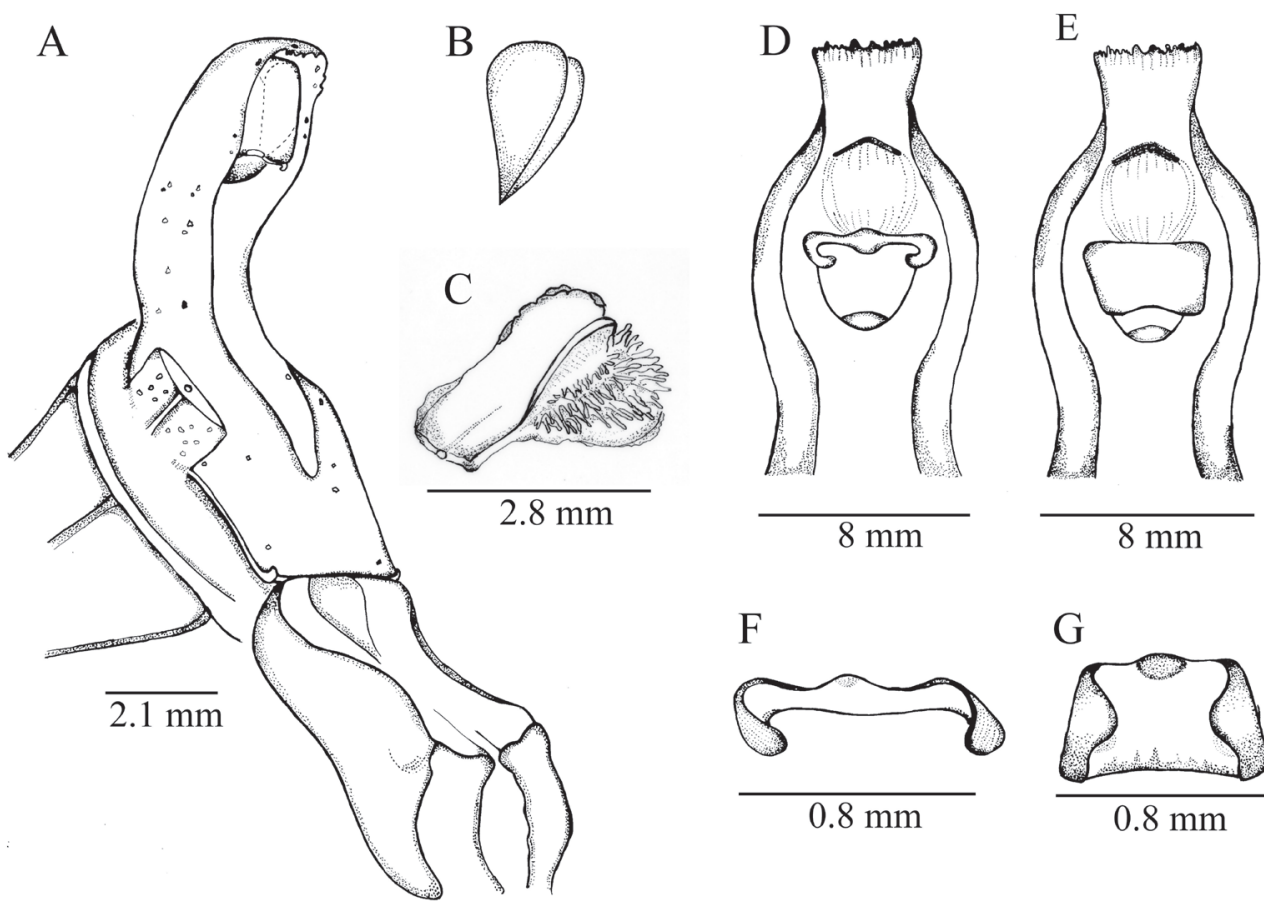

G

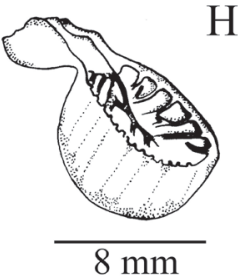

H
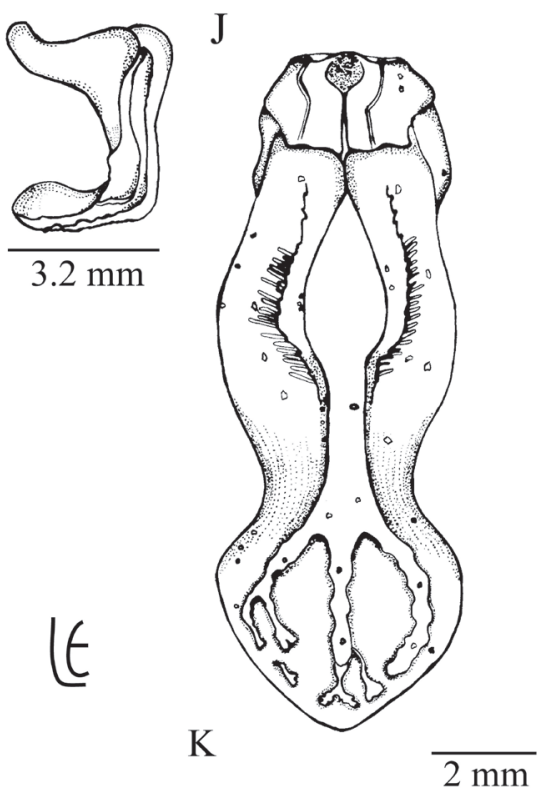

FIgURE 2. Reproductive organs of Dracula lafleurii (A-I) and D. felix (J-K); Dracula laffleurii: A — Column and hypochile with raphide crystals, petals and sepals have been removed; B — pollinia; C — bivalvate petal; D — ventral view of the column, rostellum in open position, pollinia removed; E - ventral view of the column, rostellum in closed position, pollinia removed; $\mathrm{F}$ - frontal view of the rostellum; $\mathrm{G}$ - ventral view of the rostellum; $\mathrm{H}$ - lateral view of the labellum; I - frontal view of the labellum; J - lateral view of the labellum of Dracula felix $\mathrm{K}$ - frontal view of the labellum of $D$. felix showing raphides. Illustrations by Lorena Endara. 
bed with two waxy, subhemispherical pollinia (Fig. $2 b$ ), which are separated from the stigmatic cavity by a rostellar flap with incurved margins (Fig. 2d, e, f, g). The labellum is flexibly attached to the base of the column by membranous tissue of labellar origin, which provides elasticity and allows movement of the labellum (Fig. 2a). The labellum is divided in two sections: a basal, narrow portion (hypochile) and a distal, expanded, usually concave segment (epichile) with the appearance of the gills of an inverted mushroom. In both species, the hypochile is a complex structure that has a central cleft with sinuous lateral margins (Fig. 2h, i, j, k).

The epichiles of Dracula lafleurii and D. felix differ greatly. In D. lafleurii it is subglobose with a complex inner arrangement of lamellae that radiate from the hypochile and branch outwards (Fig. 2i). Its outer surface is smooth and is covered by a lustrous film on the first day of anthesis (Fig. 1c). The epichile of $D$. felix is pandurate, shallow and concave with a rather simple network of lamellae with small raphides (Fig. $2 \mathrm{k}$ ). The lustrous film that is present in D. lafleurii was not detected in D. felix. The column, petals, and labellum hypochile frame a small space, here designated as the columnar chamber. In $D$. lafleurii, the columnar chamber measures $2.5 \times 1.5 \times 3.4 \mathrm{~mm}$, while $D$. felix measures $1.5 \times 1.3 \times 3 \mathrm{~mm}$ (height, width and depth respectively).

Flowering patterns and flower longevity.- The two orchid species have very different flowering patterns. Each Dracula lafleurii plant produces flowers in succession that are open for $11 \pm 4.5$ days $(n=8)$. Each inflorescence produces three to six flowers per season (primarily December to late May). In contrast, each $D$. felix plant has a single, synchronous, massive flowering event with 50 or more flowers/plant/year (depending on size of plant), and the flowers are open for $10 \pm 3$ days $(\mathrm{n}=40)$. The flowering period of $D$. felix varies between early January and late February, depending on the year, but within a year the mass flowering lasts only a couple of weeks. (In 1999 7-21 February; in 2002 1-15 January; in 2008 15-31 January, and in 2009 a few were flowering in the $4^{\text {th }}$ week of December, but many more had buds). We did not find evidence for sugary floral rewards; Combur ${ }^{\circledR}$ strips laid on exudates had no reaction, indicating a lack of reducing sugars.
Floral visitors and their behavior.- Most visitors of Dracula lafleurii and D. felix were flies of the family Drosophilidae, and most of them were species of Zygothrica (Table 1). With the exception of specimens 10 (Cladochaeta sp.), 22 (Drosophila [Sophophora] sp.), and 27 and 29 (Drosophila bromeliae species group), all of the drosophilids in this study are largely mycophilous. No significant difference in fly sex ratios was documented, but differences were found in the composition of the guilds visiting the two species (Table 1). Visitors of D. lafleurii and D. felix behaved differently and are thus described separately below.

Dracula lafleurii.- The total number of fly visits/ flower varied from four to 22 ( $n=5$ flowers), with the majority of visits $(64 \%)$ occurring between 0900 and $1300 \mathrm{hr}$. The earliest visit was at 07:43 and the latest at 15:58. On the first day of anthesis no visits were recorded, which coincides with the period when the labellum had a lustrous appearance (Fig. 1c). Visitation started on the second day and was most intense during the third through fifth days of anthesis, with $85 \%$ of the recorded visits taking place on these three days (Fig. 4a). Visitation rates were 72 visits/5 flowers/55 hours $=0.26$ visitors/flower/hour and the pollinia were removed from all five flowers. The flies landed either on the epichile, the inner surface of the sepals, or on the sepaline tails. Flies often perched on the sepaline tails, or they followed them toward the inner blade of the sepal and sometimes the epichile was reached (Fig. 1d). Landing was followed by resting, or by one of two activities: combing the wings with the hind legs, or repetitive lapping at the surface of the flower with their proboscis. The latter activity is the most commonly performed by visiting flies (Fig. 1e). We observed flower guarding and fidelity of flies to particular flowers. The flies spent a long time in the flowers, averaging 70.8 minutes per visit (range $=<1-323 \mathrm{~min}$ ). Visit duration depended on the day since the flower opened (ANOVA F $2.19_{6,85}, \mathrm{P}=0.0510$; Fig. 4b), with no visits occurring on the first and last $\left(7^{\text {th }}\right)$ days of observation.

Flies congregate on the inner surface of the sepaline blades or on the inner and outer portions of the labellum's epichile. During periods of high visitation (7 to 18 flies simultaneously) an interesting display of interactions occurred among visitors. Flies posed on the sepals or the epichile, or advancing towards 
Table 1. Visitors to flowers of Dracula felix and D. lafleurii. Specimens that removed pollinia are marked with an asterisk $(*)$, specimens that deposited pollinia are marked with a double asterisk $(* *), \mathrm{n} / \mathrm{d}$ indicates no data. Abbreviations: aff.=affinity, sp. $=$ species, n. sp.=new species.

\begin{tabular}{|c|c|c|c|}
\hline \multicolumn{4}{|l|}{ Dracula felix } \\
\hline Family & Visitors & q & $\hat{\sigma}$ \\
\hline Drosophilidae & $\begin{array}{l}\text { Cladochaeta } \mathrm{sp} . \\
\text { Zygothrica } \mathrm{sp} .1 \text { aff. candens-ptilialis } \\
\text { Zygothrica } \mathrm{sp} .4 \text { aff. spiculirostris, n. sp. } \\
\text { Zygothrica } \text { sp. } 5 \text { aff. spiculirostris, n. sp. *,* }\end{array}$ & 1 & $\begin{array}{c}1 \\
2 \\
1 *, * *\end{array}$ \\
\hline Sphaeroceridae & Pterogramma sp. & $\mathrm{n} / \mathrm{d}$ & $\mathrm{n} / \mathrm{d}$ \\
\hline Staphylinidae & Subfm. Aleocharinae & $\mathrm{n} / \mathrm{d}$ & $\mathrm{n} / \mathrm{d}$ \\
\hline \multicolumn{4}{|l|}{ Dracula lafleurii } \\
\hline Family & Visitors & q & $\hat{0}$ \\
\hline Drosophilidae & $\begin{array}{l}\text { Drosophila sp. (bromeliae group) } \\
\text { Drosophila sp. (subgenus Sophophora) } \\
\text { Hirtodrosophila sp. } 1 \\
\text { Hirtodrosophila sp. } 2 \text { near levigata-glabrifrons } \\
\text { Zygothrica antedispar } \\
\text { Zygothrica paraldrichi } \\
\text { Zygothrica } \mathrm{sp} .3 \text { near bilinefilia } \\
\text { Zygothrica } \mathrm{sp} .7 \text { vittatifrons group } \\
\text { Zygothrica } \mathrm{sp} .8 \text { vittatifrons group } \\
\text { Zygothrica } \mathrm{sp} .9 \text { vittatifrons group } \\
\text { Zygothrica } \mathrm{sp} .10 \text { vittatifrons group }\end{array}$ & $\begin{array}{c}1 \\
3 \\
2 \\
2 \\
3 \\
1 * * \\
1^{*} \\
1^{*}\end{array}$ & $\begin{array}{c}1 \\
1 \\
1 \\
1 \\
3 * \\
1 \\
2\end{array}$ \\
\hline Lauxaniidae & Minettia sp. & $\mathrm{n} / \mathrm{d}$ & $\mathrm{n} / \mathrm{d}$ \\
\hline
\end{tabular}

it, engaged in semaphoring (slow, repetitive, side-toside movements made with the wings when they are extended $45^{\circ}$ from each other and raised $45^{\circ}$ above the abdomen), flicking (wings extended slowly and alternately more than $90^{\circ}$ from their resting position over the abdomen), scissoring (wings simultaneously and rapidly extended about $90^{\circ}$ to the longitudinal axis of the body) and vibrating wing movements (Figs. 1f, 3a). Zygothrica antedispar advanced towards the labellum performing a different wing movement than those aforementioned. These flies lift the left wing followed by both wings and combine this with repeated lapping at the surface of the flowers. Foreleg slashing and head butting were less frequently displayed. Hirtodrosophila and the Drosophila bromeliae group visitors especially displayed these aggressive behaviors, displacing other flies in the epichile or the ones entering the columnar chamber. Some individuals of Zygothrica remained on the upper proximal surface of the labellum during their visit.
Dracula felix.- The massive flower production of this species, the erratic behavior of the small flies, and their superficial similarity to each other made it impossible to record visit duration for individual insect species, so we report only the number of visits. Normally, flies landed on the internal blade of the dorsal sepal and moved rapidly into the flower, lapping and sucking the inner surface of the sepals and eventually reaching the labellum. Visitation rates were high: 70 visits $/ 47$ flowers $/ 1.25 \mathrm{hrs}=1.19$ per flower per hour. Like in D. lafleurii, we observed flower guarding and fidelity of flies to particular flowers (Fig. 3b), but this was less pronounced on $D$. felix. Unlike in D. lafleurii, we never observed mating in the flowers of D. felix.

In addition to flies, web-building spiders (Fig. 3c) and staphylinid beetles of the subfamily Aleocharinae were occasionally observed in Dracula flowers. 


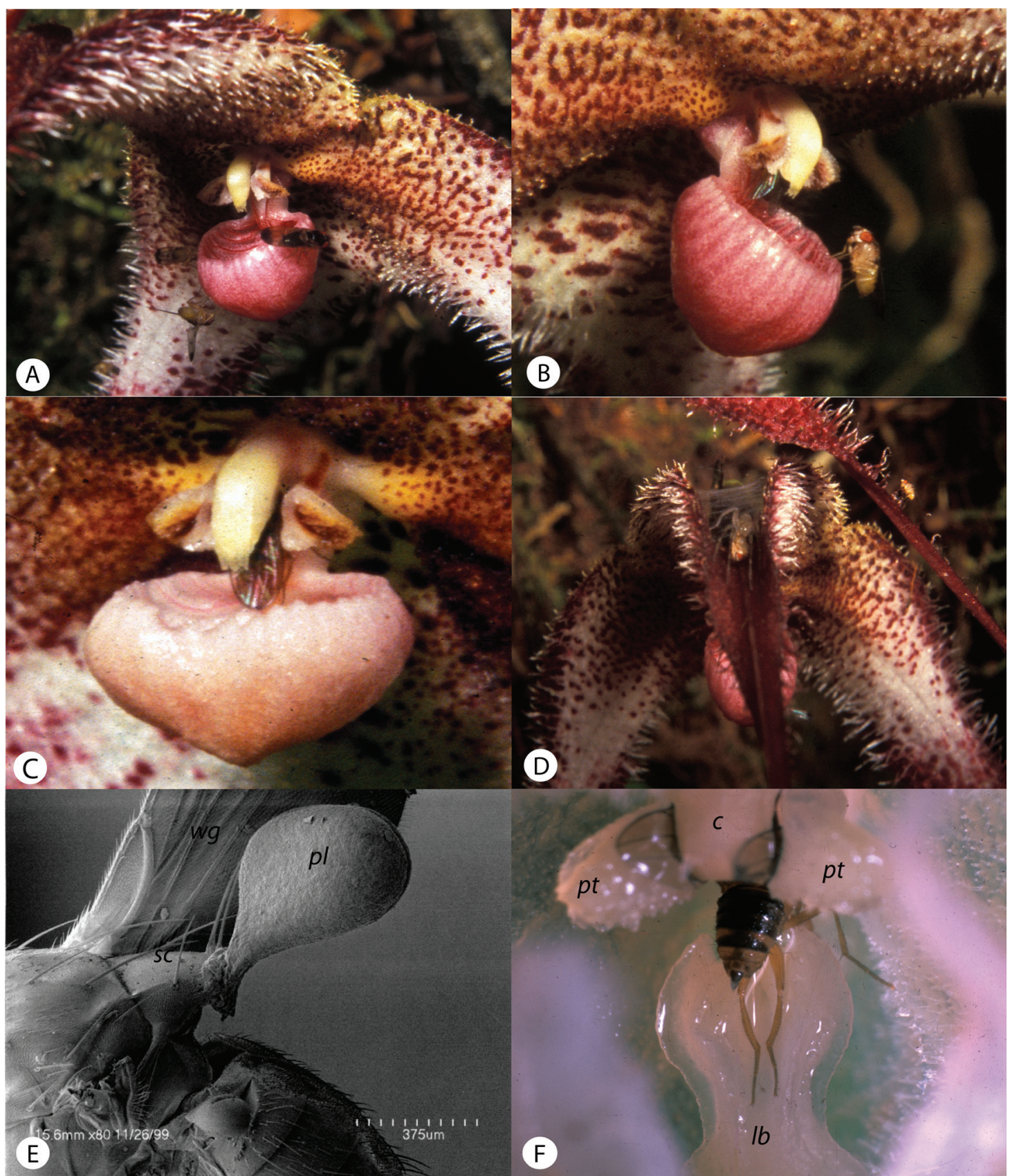

FIgURE 3. A - Lapping and semaphoring behavior displayed by visitors of Dracula lafleurii and territorial behavior on labellum; B - Zygothrica territorial behavior on D. laffleurii lip; C - A spider capturing flies on the dorsal sepal of D. lafleurii; D - Zygothrica sp. entering the columnar chamber of D. lafleurii; E - SEM of the pollinia of $D$. lafleurii attached to the scutellum of Zygothrica antedispar; wg: wing, pl: pollinia, sc: scutellum; F — Zygothrica sp. 5 (aff. spiculirostris) trapped in columnar chamber of Dracula felix; $c$ : column, pt: petal, $l b$ : labellum. 

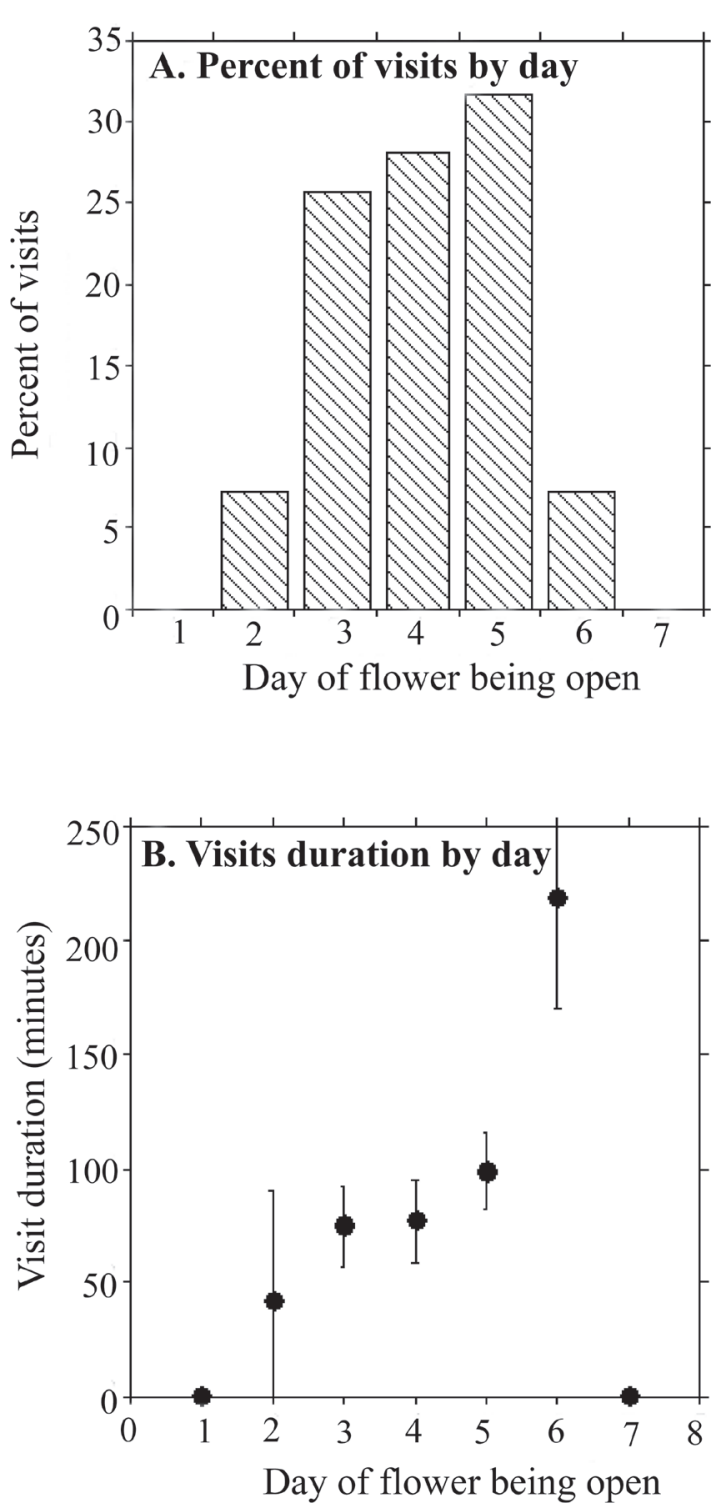

FIgURE 4. Summary of visitation by flying insects to $D$. lafleurii for each day the flowers were open $(n=5$ flowers, 72 visitors). A - percentage of total visits by day; B - duration of visits by day (mean \pm s.e.).

\section{Pollination mechanism}

Dracula lafteurii.- Flies that lap at the inner surface of the labellum epichile are guided by lamellae that radiate from the hypochile. The wings lie over the abdomen and touch the apex of the column; the fly enters into the columnar chamber (Fig. 3d) and advances towards the base of the hypochile while constantly lapping the surface. The hind legs reach a slope on the margins of the distal portion of the hypochile and the fly makes repeated attempts to advance towards the base of the hypochile, but the mid and hind legs slide on this slope, slightly pushing the labellum away from the column. The thorax of the fly is then trapped by the incurved margins of the claw-like rostellar flap (Fig. 2f, g) and attempts of the fly to move further or escape are unsuccessful. The fly's movements are interrupted by short pauses in which the legs stop moving, the labellum returns to its normal position, and the fly is gently pressed against the column. The ventral part of the fly's body rests on the central cleft of the hypochile and the thorax and abdomen form an angle that leaves the scutellum free. After alternating periods of activity and pause, the scutellum becomes coated with a sticky fluid secreted by the rostellum, which then sticks to the caudicles of the pollinia (Fig. 3e). The rostellum remains partially attached to the fly as the fly backs out and pulls the pollinia out of the anther bed. Simultaneously, the rostellum is pulled forward and covers the stigmatic cavity (Fig. $2 \mathrm{~d}, \mathrm{e})$. The loaded fly is released from the rostellum, the anther cap falls and the fly immediately leaves the columnar chamber. The duration of the process from initial trapping to pollinia removal varied from 47 to 65 minutes and was performed by three species of Zygothrica: Z. antedispar and Zygothrica spp. 9 and 10. Once liberated, flies loaded with pollinia fell into the epichile or flew to the sepals, sepaline tails or to other flowers, but no case did flies remain for extended periods in the same flower. Curiously, flies loaded with pollinia flew to other flowers and immediately tried to enter the columnar chamber of other D. lafleurii flowers. No deposition of pollinia in the stigmatic cavity was observed in this species. One fly (Zygothrica sp. 8) was found trapped in the columnar cavity probably after depositing pollinia.

Dracula felix.- The pollination process resembles that of D. lafleurii, with the main difference being that the flies visiting and pollinating these smaller flowers enter directly into the columnar chamber. Zygothrica spp. 1, 4, 5, and 8 removed pollinia, but the only pollinia deposition observed was conducted by Zygothrica $\mathrm{cf}$. antedispar. Zygothrica spp. 4 and 5 are undescribed 
species closely related to Z. spiculirostris, all of which have a distinctive, long, fine proboscis. When a fly loaded with pollinia enters the columnar chamber, the pollinia lodge into the sticky stigmatic cavity and the fly is trapped again. Flies will then spread their wings $45^{\circ}$ apart and these become pressed against the column by the inner surface of the bivalvate petals. One observed fly was liberated after the pollinia deposition, but it was common to find dead flies trapped in flowers with developing capsules in this species (Fig. 3f).

\section{Post-pollinia removal and post pollination effects}

After the pollinia have been removed in Dracula lafleurii and D. felix the rostellum moves partially forward, covering the stigmatic cavity. The rostellum returns to its original position a few minutes after the pollinia have been removed. After the deposition of pollinia, the stigmatic cavity engulfs the pollen masses and the column starts to swell. After the 7th day of being open, or after pollinia removal, flowers of $D$. lafleurii become darker at the junction of the lateral and dorsal sepals. The mobility of the labellum and its relative position to the column loosen and the labellum separates from the column. After pollinia removal or the 5 th day of the flowers being open, the fragrance stops being mushroom-like and becomes sweet instead.

\section{Discussion}

We have shown that the flowers are attractive to mycophilous flies, and that these insects pollinate them. Several species of Zygothrica and the closely related drosophilid genus Hirtodrosophila are attracted to these orchids (Courtney et al. 1990, Grimaldi 1990). Both genera are well known to congregate at fungi, particularly at white ones. A number of the flies we found were undescribed. This genus is large, and primarily Neotropical with approximately 120 described species and perhaps an additional 100 as yet undescribed species (Grimaldi 1987); it is only partially revised taxonomically.

We observed that some Zygothrica species aggressively defend their territory from other males on the sepals of a Dracula flower, while others defend their territory on top of the labellum, analogous to the pilei of mushrooms in the same way that some Zygothrica partition their territories on mushrooms (Burla 1990). In contrast, other non-Zygothrica visitors approached any small dark insect silhouetted against the white surface and displayed various wing movements regardless of conspecificity. The aggregation and courtship behavior triggered by small dark forms suggests that the small dots on most Dracula sepals may serve as a visual attractant for these mycophilous flies. Moreover, the pigmented wings of $Z$. paraldrichi (Fig. 1f, showing scissoring movement) and $Z$. antedispar bear remarkable resemblance to the petals of most Dracula species, leading us to hypothesize that the petals could trigger mating behavior in the flies and prompt them to approach the columnar chamber. While we observed courtship and mating in the flowers, no eggs were discovered in the flowers.

Fragrances are likely to be important for attracting the flies that visit Dracula. While Dracula felix has little human-observable fragrance, D. lafleurii smells mushroom-like and mushroom fragrance compounds have been isolated from other Dracula species (Kaiser 2006). Flies approached D. lafleurii flowers with a seemingly scent-oriented flight (directly, in a spiral or in a zigzag pattern), and some hovered near the labellum before landing on it. Other visitors hovered at $5 \mathrm{~cm}$ or less in front of the flower before landing on the sepals. To understand the links between fragrance, mimicry and pollinator behavior, future work with Dracula fragrances should document the extent of natural variation and selection acting on it.

The number and diversity of Zygothrica flies coming to Dracula flowers was remarkable, with at least five species of drosophilids from the present study being new to science. Zygothrica flies were the only ones that carried pollinia and are the best suited as pollinators of the insect visitors observed. For example, it is unlikely that Cladochaeta and Hirtodrosophila visitors, due to their smaller size, would be able to remove or deposit pollinia. However, it is interesting that two of these three fly genera are primarily mycophagous (Grimaldi \& Nguyen 1999). The larvae of Minnetia and Pterogramma are saprophagous and those of Cladochaeta are mostly parasites of spittlebugs or they feed within flowers (Grimaldi \& Nguyen 1999). In the case of Minnetia, large quantities of fungal spores and hyphae are usually present in their guts (Broadhead 1984).

LANKESTERIANA 10(1), April 2010. (C) Universidad de Costa Rica, 2010. 
While a number of species of Zygothrica visited each species of Dracula, the two orchids did not share visitors (Table 1). This is not too surprising given that these particular orchids mostly grow in different habitats (mountain ridges for D. felix and river valleys for $D$. lafleurii), and the flowers are very different in overall size and morphology (see figures). However, hybridization has been reported for other Dracula species growing in ex situ (Luer 1989) and several specimens with unclear species boundaries and putative natural hybrids have been collected in disturbed sites (Endara pers. obs.). Given our data showing that many species of Zygothrica flies can remove pollinia from Dracula orchids, and studies that have shown little specificity of mycophagous flies to particular mushrooms (Courtney et al. 1990), rampant hybridization would seem likely.

An important question remains: What is the nature of the film that forms on the labellum the first day the flowers are open? Do these flowers provide fluid nutrition through the production of putrefying or deliquescing fluid? Repetitive lapping by Zygothrica and other flies suggest that the flies are grazing on some sort of liquid film. The lack of sugar indicated by the tests could have resulted from several factors, including: (1) not testing on the proper day (we only tested on the first day the flowers were open, though that was also the only time we saw anything that could be interpreted as a liquid), (2) low concentrations of sugars, (3) tests that are not sensitive to the sugars present in this film or, (4) a film that is composed mostly of lipids, proteins, or amino acids that could serve as growth medium to yeast that is part of mycophilus flies (Labandeira, 2005). Alternatively, the lapping behavior is reminiscent of the same behavior exhibited by Drosophila males during courtship (Sturtevant 1915, Howard and Blomquist 1982; Ferveur 2007).

Synthesis and Conclusions.- Similar to mushrooms, Dracula flowers serve as shelters and rendezvous sites for flies during the prolonged rainy season, a potential explanation for the tendency of extended visits by these flies (Fig. 4b). Despite the violent disturbances caused to the flowers by droplets of water, the spreading sepals create a roof-like structure that protects the flower's reproductive organs and insect visitors. The incurved margins of the rostellar flap and the base of the petals, so crucial in pollination, also play an important role in preventing the expulsion of the pollinator from the flower during rainy periods. The incurved margins of the rostellar flap of Dracula flowers were not mentioned in the original species descriptions, which is not surprising since these structures are minute. To our knowledge, the only previous account of this structure an illustration of the column of Dracula bella (formerly Masdevallia bella, Woolward 1896), which shows a frontal view of the rostellum's incurved margins. The importance of this structure would not have been noticed until their role in the pollination mechanism was observed.

ACKNOWLEDGEMENTS. For support at various times during the project we thank: J. de Coux, R. Valencia, N. Pitman, the staff at Herbario Pontificia Universidad Católica del Ecuador QCA, Herbario Nacional del Ecuador (QCNE), and all the staff at Los Cedros Biological Reserve. Image $1 \mathrm{E}$ was kindly provided by Murray Cooper. Several people provided valuable comments on the manuscript: Mario Blanco, Steven Beckendorf, Bryn Dentinger, Lou Jost, Carl Luer, Kurt Neubig, Steven Johnson, Tobias Policha, Mark Whitten, Norris Williams, and anonymous reviewers. Funding for this work was provided in part by the Global Environmental Facility (GEF) Activity 16 and the San Diego County Orchid Society to L. Endara and the National Geographic Society (NGS grant No. 8317-07) to B. A. Roy and B. T. M. Dentinger, and by a grant from the National Science Foundation (DEB-0841613) to B. A. Roy and B. T. M. Dentinger. Research permits for this project $(0031 \mathrm{C}$ INEFAN/DNA/NVF/VS) and (001-07 IC-F-DRCI-MA) were facilitated by Ministerio del Ambiente de Ecuador.

\section{LITERATURE CITED}

Albores-Ortiz, O. \& V. Sosa. 2006. Polinización de dos especies simpátricas de Stelis (Pleurothallidinae, Orchidaceae). Acta Bot. Mex. 74: 155-167.

Blanco, M.A. \& G. Barboza. 2005. Pseudocopulatory pollination in Lepanthes (Orchidaceae: Pleurothallidinae) by fungus gnats. Ann. Bot. 95: 763-772.

Barbosa, A.R., M.C. de Melo, E.L. Borba. 2009. Selfincompatibility and myophyily in Octomeria (Orchidaceae, Pleurothallidinae) species. Plant. Syst. Evol. 283:1-8.

Borba, E.L.\& J. Semir. 2001. Pollinator specificity and convergence in fly-pollinated Pleurothallis (Orchidaceae) species: A multiple population approach. Ann. Bot. 88: 75-88. 
Broadhead, E. 1984. Adaptations for fungal grazing in lauxaniid flies. J. Nat. His. (London) 18: 639-649.

Burla, H. 1990. Lek behavior in hypercephalic Zygothrica dispar Wiedemann (Diptera, Drosophilidae). Zeitschrift fur Zoologische Systematik und Evolutionsforschung 28: 69-77.

Chase, M.W. 1985. Pollination of Pleurothallis endotrachys. Amer. Orchid Soc. Bull. 54: 431-434.

Christensen, D.E. 1994. Fly pollination in the Orchidaceae. In: J. Arditti [ed.], Orchid Biology: Reviews and perspectives, VI, 415-454. John Wiley \& Sons, New York, USA.

Courtney, S.P., T.T. Kibota, \& T.A. Singleton. 1990. Ecology of mushroom-feeding Drosophilidae. In: M. Begon, A. H. Fitter, and A. Macfadven [eds.], Advances in ecological research, 225-274. Academic Press.

Dressler, R. 1993. The orchids: Natural history and classification. Harvard University Press, Cambridge, Massachusetts, USA.

Duque, O. 1993. Polinización en Pleurothallis. Orquideología 19: 55-69.

Endress, P.K. 1996. Diversity and evolutionary biology of tropical flowers. Cambridge University Press, Cambridge, United Kingdom.

Ferveur, J.F. 2007. Elements of courtship behavior in Drosophila. In: G. North and R. J. Greenspan [eds.], Invertebrate Neurobiology. Cold Spring Harbor Laboratory Press, New York, New York, USA.

Grimaldi, D.A. 1987. Phylogenetics and taxonomy of Zygothrica (Diptera, Drosphilidae). Bull. Amer. Mus. Nat. Hist. 186: 107-268.

Grimaldi, D.A. 1990. A phylogenetic, revised classification of genera in the Drosophilidae (Diptera). Bull. Amer. Mus. Nat. Hist. 197: 1-139.

Grimaldi, D.A. \& T. Nguyen. 1999. Monograph on the spittlebug flies, genus Cladochaeta (Diptera, Drosophilidae, Cladochaetini). Bull. Amer. Mus. Nat. Hist. 241: 1-326.

Howard, R. W., AND G. J. Blomquist. 1982. Chemical ecology and biochemistry of insect hydrocarbons. Annu. Rev. Entomol. 27: 149-172.

Jørgensen, P.M. \& S. Léon-Yánez. 1999. Catalogue of the Vascular Plants of Ecuador. Missouri Botanical Garden Press, St. Louis, Missouri, USA.
Kaiser, R. 2006. Flowers and fungi use scents to mimic each other. Science 311: 806-807.

Labandeira, C.C. 2005. Fossil history and evolutionary ecology of Diptera and their association with plants. In: D. K. Yates and B. Wiegmann [eds.], The evolutionary biology of flies, 217-273. Columbia University Press, New York, New York, USA.

Luer, C.A. 1978. Dracula, a new genus in the Pleurothallidinae. Selbyana 2: 190-198.

Luer, C.A. 1989. Spontaneous hybrids in Dracula. American Orchid Society Bulletin 58: 981-986.

Luer, C.A. 1993. Icones Pleurothallidinarum X. Systematics of Dracula (Orchidaceae). Missouri Botanical Garden Press, St. Louis, Missouri, USA.

Luer, C.A., AND R. Escobar. 1994. Thesaurus Dracularum VII. Missouri Botanical Garden Press, St. Louis, Missouri, USA.

Pridgeon, A.M. 2005. Dracula. In: A. Pridgeon, P. Cribb, M. Chase, \& F. Rasmussen [eds.], Genera Orchidacearum Volume 4 - Epidendroideae (Part One). Oxford University Press, Oxford, United Kingdom.

Pridgeon, A.M., R. Solano, \& M.W. Chase. 2001. Phylogenetic relationships in Pleurothallidinae (Orchidaceae): combined evidence from nuclear and plastid DNA sequences. Amer. J. Bot. 88: 22862308.

Pridgeon, A., P.J. Cribb, M.W. Chase., F.N. Rasmussen. 2005. Genera Orchidacearum volume 4 - Epidendroideae (Part One), Oxford University Press, Oxford, U.K.

Proctor, M., P. Yeo \& A. Lack. 1996. The natural history of pollination. Timber Press, Portland, Oregon, USA.

Sturtevant, A. H. 1915. Experiments in sexual recognition and the problems of sexual selection in Drosophila. Anim. Behav. 5: 351-366.

Van der Cingel, N.A. 2001. An atlas of orchid pollination - America, Africa, Asia and Australia. A.A. Balkema, Rotterdam, The Netherlands.

Van der Pijl, L. \& C. H. Dodson. 1966. Orchid flowers: their pollination and evolution. University of Miami Press, Coral Gables, Florida, USA.

Vogel, S. 1978. Pilzmückenblumen als Pilzmimeten. Flora (Germany) 167: 329-398.

Woolward, F.C. 1896. The genus Masdevallia. R. H. Porter, London, United Kingdom. 
